\title{
Flavobacterium aquidurense sp. nov. and Flavobacterium hercynium sp. nov., from a hard-water creek
}

\author{
Sylvie Cousin, Orsola Päuker and Erko Stackebrandt
}

\author{
Correspondence \\ Sylvie Cousin \\ sylvie.cousin@dsmz.de
}

\author{
DSMZ - Deutsche Sammlung von Mikroorganismen und Zellkulturen GmbH, Mascheroder Weg \\ 1b, D-38124 Braunschweig, Germany
}

\begin{abstract}
Ten new Flavobacterium-like strains were isolated from freshwater of the hard-water creek Westerhöfer Bach, northern Germany. These strains formed two phylogenetic groups: strains WB 1.1-56 ${ }^{\top}$, WB 1.1-04, WB 1.1-14, WB 1.1-57 and WB 1.1-63; and strains WB 4.2-33 ${ }^{\top}$, WB 4.1-86, WB 4.2-34, WB 4.2-32 and WB 4.2-78. Cells were Gram-negative, yellow-pigmented, chemoheterotrophic rods. Their major fatty acid profiles were similar, consisting of iso- $\mathrm{C}_{15: 0}$, iso- $\mathrm{C}_{15: 0} 3-\mathrm{OH}$, iso- $\mathrm{C}_{17: 0} 3-\mathrm{OH}$ and summed feature $3\left(\mathrm{C}_{16: 1} \omega 7 \mathrm{c}\right.$ and/or iso- $\left.\mathrm{C}_{15: 0} 2-\mathrm{OH}\right)$. DNA $\mathrm{G}+\mathrm{C}$ contents for strains WB $1.1-56^{\top}$ and $\mathrm{WB} 4.2-33^{\top}$ were 33.5 and $37.5 \mathrm{~mol} \%$, respectively. Phylogenetic analysis based on almost complete 16S rRNA gene sequences indicated that strain WB 1.1-56 ${ }^{\top}$ was phylogenetically most closely related to Flavobacterium frigidimaris KUC $-1^{\top}$, and that strain WB $4.2-33^{\top}$ was related most closely to $F$. frigidimaris $\mathrm{KUC}-1^{\top}$ and Flavobacterium saccharophilum DSM $1811^{\top}$. Levels of $16 \mathrm{~S}$ rRNA gene sequence similarity between strains WB $1.1-56^{\top}$ and WB $4.2-33^{\top}$ and the type strains of recognized members of the genus Flavobacterium were below $98 \%$. DNA-DNA hybridization experiments confirmed the separate genomic status of strains WB $1.1-56^{\top}$ and WB $4.2-33^{\top}$. Strains WB $1.1-56^{\top}$ and WB 4.2-33 ${ }^{\top}$ and their respective relatives differed from phylogenetically related Flavobacterium species based on several phenotypic characteristics. On the basis of their phenotypic and phylogenetic distinctiveness, the two groups of strains are considered to represent two novel species, for which the names Flavobacterium aquidurense sp. nov. (type strain WB $1.1-56^{\top}=\mathrm{DSM} 18293^{\top}=\mathrm{CIP}$ $109242^{\top}$ ) and Flavobacterium hercynium sp. nov. (type strain WB $4.2-33^{\top}=\mathrm{DSM} 18292^{\top}=\mathrm{CIP}$ $109241^{\mathrm{T}}$ ) are proposed.
\end{abstract}

The genus Flavobacterium Bergey et al. 1923 belongs to the family Flavobacteriaceae in the phylum Bacteroidetes. With emendation of the description of the genus (Bernardet et al., 1996), several species previously belonging to the genus were reclassified and placed in new or different genera. Recently, Bernardet \& Bowman (2005) provided an excellent overview of the taxonomy and ecology of members of the genus Flavobacterium. Species of the genus have been isolated worldwide from habitats such as marine and freshwater environments, soil, sediment, sea-ice biofilms and diseased fish. In the past few years, many novel species have been added to the genus, isolated from freshwater sediments (Tamaki et al., 2003; Wang et al., 2006), glacier ice (Zhu

The GenBank/EMBL/DDBJ accession numbers for the $16 \mathrm{~S}$ rRNA gene sequences of WB 1.1-56 ${ }^{\top}, W B \quad 4.2-33^{\top}$ and $W B$ 4.2-78 are AM177392, AM265623 and AM177627, respectively.

A table giving the fatty acid compositions of the novel strains and related members of the genus Flavobacterium and a dendrogram based on these results are available as supplementary material in IJSEM Online. et al., 2003), soil (Yoon et al., 2006; Kim et al., 2006), Antarctic habitats (McCammon \& Bowman, 2000; Humphry et al., 2001; Van Trappen et al., 2003, 2004, 2005; Yi et al., 2005; Nogi et al., 2005; Yi \& Chun, 2006), the gut of an earthworm (Horn et al., 2005) and bacterial aggregates of a wastewater treatment plant (Aslam et al., 2005). A rich diversity of flavobacteria has also been reported from river epilithon (O'Sullivan et al., 2006). In a recent study on the diversity of freshwater bacteria, hundreds of Gram-negative, rod-shaped Flavobacteriumlike bacteria were isolated from water of a hard-water creek from the western slopes of the Harz Mountains, Germany. Following a pre-screening by MALDI-TOF mass spectrometry (Brambilla et al., 2007) and partial 16S rRNA gene sequence analysis, several groups of isolates were found to cluster separately from the type strains of recognized members of the genus Flavobacterium. Two of these groups were subjected to a polyphasic taxonomic study.

Isolation of strains from the Westerhöfer Bach has been described by Brambilla et al. (2007). Strains WB 1.1-56 ${ }^{\mathrm{T}}$, 
WB 1.1-04, WB 1.1-14, WB 1.1-57 and WB 1.1-63 were isolated from spring water, and strains $\mathrm{WB} 4.2-33^{\mathrm{T}}$, WB 4.186, WB 4.2-34, WB 4.2-32 and WB 4.2-78 were isolated from creek water about $320 \mathrm{~m}$ downstream from this spring (station 4). Following isolation on R2A medium (Difco) strains were transferred to and maintained on medium 67 (M67; DSMZ, 2001) at $25^{\circ} \mathrm{C}$ for at least $24 \mathrm{~h}$. The same medium was also used to cultivate the reference strains Flavobacterium saccharophilum DSM $1811^{\mathrm{T}}$, Flavobacterium frigidimaris DSM $15937^{\mathrm{T}}$, Flavobacterium flevense DSM $1076^{\mathrm{T}}$ and Flavobacterium pectinovorum DSM $6368^{\mathrm{T}}$.

DNA extraction and PCR amplification of the 16S rRNA genes were carried out as described by Rainey et al. (1996). The PCR amplificate was purified by using the QIAquick PCR purification kit (Qiagen) according to the manufacturer's instructions. Sequencing of the PCR products, manual alignment of the sequences with those of recognized Flavobacterium species and determination of similarity coefficients were performed as described by Rainey et al. (1996). The algorithm of De Soete (1983) and the neighbour-joining algorithm (Felsenstein, 1993) were used to generate tree topologies. Bootstrap values were calculated according to Felsenstein (1985).

All strains were first subjected to partial 16S rRNA gene sequence analysis (436 bp, 5' terminus). The five strains isolated from the spring water showed $100 \%$ sequence similarity to each other. The partial $16 \mathrm{~S}$ rRNA gene sequences of the five strains isolated from station 4 showed between 98.6 and $100 \%$ similarity to each other.

The almost complete sequences of the $16 \mathrm{~S}$ rRNA gene were determined for strains $\mathrm{WB} 1.1-56^{\mathrm{T}}, \mathrm{WB} 4.2-33^{\mathrm{T}}$ and $\mathrm{WB}$ 4.2-78. The sequences of the type strains of $F$. saccharophilum and F. pectinovorum were reanalysed because of sequence ambiguity in the data deposited in public databases. A sequence similarity value of $97.9 \%$ was found between strains $\mathrm{WB} 1.1-56^{\mathrm{T}}$ and $\mathrm{WB} 4.2-33^{\mathrm{T}}$. These two novel strains showed $16 \mathrm{~S}$ rRNA gene sequence similarity values of less than $98 \%$ to the type strains of recognized members of the genus Flavobacterium. Strain WB 1.1-56 was related most closely to $F$. frigidimaris DSM $15937^{\mathrm{T}}$ $(97.9 \%)$, and WB $4.2-33^{\mathrm{T}}$ to F. saccharophilum DSM $1811^{\mathrm{T}}$ $(96.7 \%)$. None of the other recognized type strains of the genus Flavobacterium clustered closely to strains WB 1.1-56 ${ }^{\mathrm{T}}$ or WB $4.2-33^{\mathrm{T}}$. A neighbour-joining tree showing the phylogenetic position of strains WB $1.1-56^{\mathrm{T}}$, WB $4.2-33^{\mathrm{T}}$ and WB 4.2-78 among related members of the genus Flavobacterium is shown in Fig. 1. The topologies of the trees generated with the neighbour-joining method and the algorithm of De Soete (1983) were almost identical. Only a few branch points of the dendrogram were supported by high bootstrap values, which is consistent with published data (Brambilla et al., 2007). The 16S rRNA gene sequences of strains WB $4.2-33^{\mathrm{T}}$ and $\mathrm{WB} 4.2-78$ were identical.

The $\mathrm{G}+\mathrm{C}$ content of the DNA of strains WB $1.1-56^{\mathrm{T}}$ and WB $4.2-33^{\mathrm{T}}$ was determined from $T_{\mathrm{m}}$ values according to

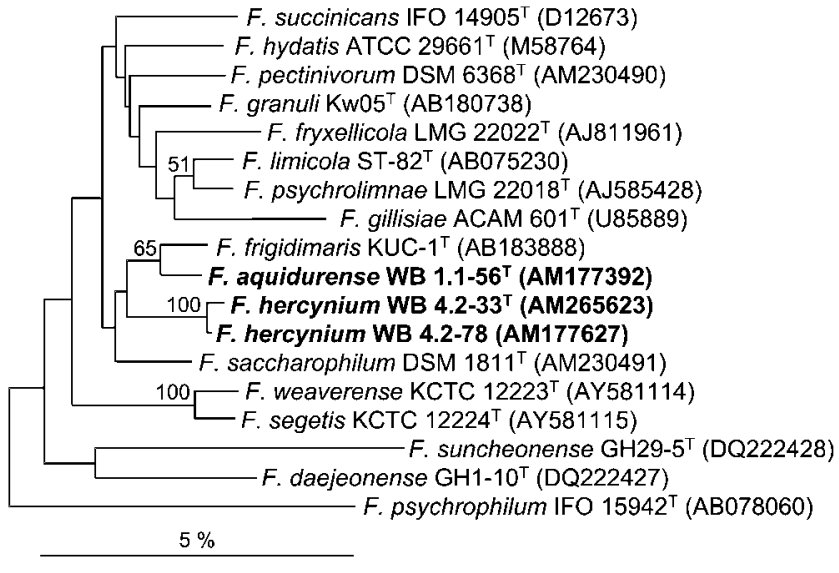

Fig. 1. Relationship between strains WB $1.1-56^{\top}$, WB $4.2-33^{\top}$ and WB 4.2-78 and the type strains of neighbouring Flavobacterium species. The dendrogram is based on $16 \mathrm{~S}$ rRNA gene sequence comparisons using the neighbour-joining algorithm of Felsenstein (1993). Numbers at branch points are bootstrap values $>50 \%$ (500 resamplings). Bar, $5 \%$ sequence divergence, as determined by measuring the length of the horizontal lines connecting any two species. The sequences of less closely related Flavobacterium species served as a root.

the formula of Frank-Kamenetskii (1971). The G+C content of strains $\mathrm{WB} 1.1-56^{\mathrm{T}}$ and $\mathrm{WB} 4.2-33^{\mathrm{T}}$ was 33.5 and $37.5 \mathrm{~mol} \%$, respectively. These values are consistent with those of recognized members of the genus Flavobacterium, which range from 30 to $37 \mathrm{~mol} \%$ (Bernardet et al., 1996; Van Trappen et al., 2003).

Genomic relatedness between strains WB $1.1-56^{\mathrm{T}}$ and $\mathrm{WB}$ $4.2-33^{\mathrm{T}}$ and their most closely related phylogenetic neighbours, i.e. the type strains of $F$. frigidimaris and $F$. saccharophilum, was determined according to the spectrophotometric DNA-DNA reassociation method. DNA was isolated using a French pressure cell (Thermo Spectronic) and was purified by hydroxyapatite chromatography as described by Cashion et al. (1977). DNA-DNA hybridization was carried out as described by De Ley et al. (1970), with the modifications of Huß et al. (1983) and Escara \& Hutton (1980), by using a model Cary 100 Bio UV/VIS-spectrophotometer equipped with a Peltier-thermostatted $6 \times 6$ multicell changer and a temperature controller with in-situ temperature probe (Varian). Hybridization values were determined at least twice for any given strain pair. Strain WB $1.1-56^{\mathrm{T}}$ was moderately related to $F$. saccharophilum DSM $1811^{\mathrm{T}}(60.5 \%)$, while reassociation values with $F$. frigidimaris DSM $15937^{\mathrm{T}}(26.2 \%)$ and with WB $4.2-33^{\mathrm{T}}$ and $\mathrm{WB}$ 4.2-78 (5.2 and 8.1\%, respectively) were significantly lower. Strain WB $4.2-33^{\mathrm{T}}$ shared $100 \%$ DNA-DNA relatedness with strains WB 4.2-78 and WB 4.1-86, i.e. two other members of the same $16 \mathrm{~S}$ rRNA gene cluster. Reassociation values for strains $\mathrm{WB} 4.2-33^{\mathrm{T}}$ and $\mathrm{WB} 4.2-78$ with $F$. frigidimaris DSM $15937^{\mathrm{T}}$ and F. saccharophilum DSM $1811^{\mathrm{T}}$ were low, ranging between $31.4-41.8$ and $44.0 \%$. These 
values indicate that the two new strain groups represent two distinct novel Flavobacterium genospecies.

The ten novel strains were subjected to fatty acid methyl ester analysis in order to determine their chemotaxonomic coherence. Also included were their closest phylogenetic neighbours, F. saccharophilum DSM $1811^{\mathrm{T}}$ and F. frigidimaris DSM $15937^{\mathrm{T}}$, as well as the type strains of Flavobacterium denitrificans, F. pectinovorum, F. flevense and Flavobacterium hibernum. Fatty acids were extracted and analysed (Miller, 1982) according to the standard protocol of the Microbial Identification System (MIDI Microbial ID Inc.) by using the TSBA40 method. Extracts were analysed by using a Hewlett Packard model HP6890A gas chromatograph equipped with a flame-ionization detector as described by Kämpfer \& Kroppenstedt (1996). The major compounds identified in the novel strains were iso- $\mathrm{C}_{15: 0}$, iso- $\mathrm{C}_{15: 0} 3$ $\mathrm{OH}$, iso- $\mathrm{C}_{17: 0} 3-\mathrm{OH}$ and summed feature $3\left(\mathrm{C}_{16: 1} \omega 7 c\right.$ and/or iso- $\mathrm{C}_{15: 0} 2-\mathrm{OH}$ ) (Table 1; the complete data set is given in Supplementary Table S1 in IJSEM Online). These fatty acids are generally present in recognized members of the genus Flavobacterium. WB $1.1-56^{\mathrm{T}}$ and related strains contained larger amounts of $\mathrm{C}_{15: 0} 3-\mathrm{OH}, \mathrm{C}_{15: 0}, \mathrm{C}_{15: 1} \omega 6 c$, iso- $\mathrm{C}_{17: 1} \omega 9 c$ and $\mathrm{C}_{17: 1} \omega 6 c$ fatty acids than strain WB $4.2-33^{\mathrm{T}}$ and its relatives. The latter strain group possessed larger amounts of $\mathrm{C}_{16: 0}$ and $\mathrm{C}_{16: 0} 3-\mathrm{OH}$, a feature also found for $F$. frigidimaris DSM $15937^{\mathrm{T}}$. The main fatty acid differences between the novel strains and their closest described relatives consist of variations in the relative amounts of less abundant and minor components. Supplementary Fig. S1 (see IJSEM Online) provides a dendrogram of fatty acid similarities in which the Euclidean distances reveal the coherence of the two new strain clusters $(<6 \%)$. On the basis of fatty acid similarities, F. denitrificans DSM $15936^{\mathrm{T}}$ and F. pectinovorum DSM $6368^{\mathrm{T}}$ group with F. saccharophilum DSM $1811^{\mathrm{T}}$, while F. flevense DSM $1076^{\mathrm{T}}$ and F. hibernum DSM $12611^{\mathrm{T}}$ group with $F$. frigidimaris DSM $15937^{\mathrm{T}}$. None of these type strains cluster closely with the novel strains.

In order to test whether the novel genospecies could also be defined in terms of their phenotypic properties, they were subjected to cultural, biochemical and morphological analyses. The results are given in Table 2 and in the species descriptions below. Growth was measured by reading the $\mathrm{OD}$ at $560 \mathrm{~nm}$.

The temperature optimum for growth was tested using a temperature gradient incubator model TN-3 (Toyo Kagaku Sangyo Co.) in $1{ }^{\circ} \mathrm{C}$ steps from 4 to $36^{\circ} \mathrm{C}$. Strains were grown in R2A medium for $12 \mathrm{~h}$.

The optimal $\mathrm{pH}$ for growth was tested in buffered M67 at $25^{\circ} \mathrm{C}$ between pH 5.8 and 8.4 , with steps of $0.2 \mathrm{pH}$ units. Salt tolerance was tested on R2A medium supplemented with $1-6 \% \mathrm{NaCl}$, in $1 \%$ step increases. Reading was after 1 day of incubation.

Colony morphology was determined on M67, R2A, nutrient agar (NA) and trypticase soy agar (TSA) (both Difco),
Table 1. Fatty acid composition of strains WB $1.1-565^{\top}$ and WB $4.2-33^{\top}$ and related strains and reference type strains of phylogenetically related members of the genus Flavobacterium

Strains: $1, \mathrm{WB} 1.1-565^{\mathrm{T}}$ and relatives $(n=5) ; 2, \mathrm{WB} 4.2-33^{\mathrm{T}}$ and relatives $(n=5)$ (values in columns 1 and 2 are means \pm SD); $3, F$. denitrificans DSM $15936^{\mathrm{T}}$; 4, F. saccharophilum DSM $1811^{\mathrm{T}} ; 5, F$. pectinovorum DSM $6368^{\mathrm{T}} ; 6$, F. frigidimaris DSM $15937^{\mathrm{T}} ; 7$, F. flevense DSM $1076^{\mathrm{T}} ; 8$, F. hibernum DSM $12611^{\mathrm{T}}$. Fatty acids accounting for $<1 \%$ are omitted. All data are percentages of total fatty acids and were obtained in this study (TSBA40 method). A more detailed analysis is provided in Supplementary Table S1 in IJSEM Online. ND, Not detected; tr, trace $(<1 \%$ of total).

\begin{tabular}{|c|c|c|c|c|c|c|c|c|}
\hline Fatty acid & 1 & 2 & 3 & 4 & 5 & 6 & 7 & 8 \\
\hline $\mathrm{C}_{14: 0}$ & $\operatorname{tr}$ & $1.5 \pm 0.1$ & $\operatorname{tr}$ & $\operatorname{tr}$ & $\operatorname{tr}$ & $\operatorname{tr}$ & ND & $\operatorname{tr}$ \\
\hline iso- $\mathrm{C}_{15: 1} \mathrm{G}$ & $6.0 \pm 0.2$ & $6.1 \pm 0.2$ & 5.4 & 5.4 & 5.6 & 3.0 & 5.0 & 3.6 \\
\hline iso- $\mathrm{C}_{15: 0}$ & $15.1 \pm 1.1$ & $23.0 \pm 0.1$ & 21.8 & 20.12 & 25.1 & 14.8 & 13.7 & 17.4 \\
\hline anteiso- $\mathrm{C}_{15: 0}$ & $2.8 \pm 0.3$ & $3.1 \pm 0.4$ & 2.1 & 3.1 & 3.5 & 3.5 & 6.2 & 1.8 \\
\hline $\mathrm{C}_{15: 1} \omega 6 c$ & $6.7 \pm 0.5$ & $1.4 \pm 0.3$ & 3.8 & 3.5 & 1.2 & 2.4 & 2.3 & 3.3 \\
\hline $\mathrm{C}_{15: 0}$ & $7.1 \pm 0.7$ & $1.6 \pm 0.2$ & 7.1 & 5.4 & 1.9 & 3.3 & 5.6 & 5.8 \\
\hline $\mathrm{C}_{16: 0}$ & $\operatorname{tr}$ & $3.4 \pm 0.3$ & 1.4 & 1.6 & 1.8 & 3.6 & 3.8 & 4.7 \\
\hline $\begin{array}{c}\text { iso- } \mathrm{C}_{15: 0} \\
3-\mathrm{OH}\end{array}$ & $8.3 \pm 0.5$ & $7.1 \pm 0.2$ & 6.8 & 9.4 & 11.5 & 7.4 & 6.0 & 8.4 \\
\hline iso- $\mathrm{C}_{17: 1} \omega 9 c$ & $8.2 \pm 0.3$ & $3.4 \pm 0.1$ & 13.5 & 8.5 & 9.0 & 4.0 & 2.44 & 4.5 \\
\hline $\mathrm{C}_{15: 0} 3-\mathrm{OH}$ & $2.8 \pm 0.1$ & ND & ND & $\mathrm{ND}$ & ND & ND & 1.3 & ND \\
\hline $\mathrm{C}_{17: 1} \omega 6 c$ & $6.4 \pm 0.7$ & $\operatorname{tr}$ & 4.2 & 2.9 & $\operatorname{tr}$ & 2.6 & 2.6 & 2.1 \\
\hline $\begin{array}{c}\text { iso- } \mathrm{C}_{16: 0} \\
3-\mathrm{OH}\end{array}$ & $2.3 \pm 0.1$ & $1.1 \pm 0.1$ & 1.1 & 3.0 & 1.4 & 2.5 & 1.8 & 3.1 \\
\hline $\mathrm{C}_{16: 0} 3-\mathrm{OH}$ & $1.7 \pm 0.1$ & $6.7 \pm 0.3$ & $\operatorname{tr}$ & 1.8 & 2.1 & 7.1 & 5.8 & 4.9 \\
\hline $\begin{array}{c}\text { iso- } \mathrm{C}_{17: 0} \\
3-\mathrm{OH}\end{array}$ & $11.6 \pm 0.7$ & $7.5 \pm 0.3$ & 11.3 & 14.8 & 14.9 & 9.1 & 8.17 & 10.4 \\
\hline $\begin{array}{l}\text { Summed } \\
\text { feature } 3^{\star}\end{array}$ & $11.8 \pm 0.9$ & $26.1 \pm 0.6$ & 10.9 & 10.5 & 13.22 & 25.4 & 27.7 & 19.9 \\
\hline $\begin{array}{l}\text { Summed } \\
\text { feature } 4^{*}\end{array}$ & ND & $1.19 \pm 0.09$ & 1.9 & 2.3 & 1.6 & 1.9 & ND & 1.4 \\
\hline
\end{tabular}

${ }^{*}$ Summed feature 3 comprises $\mathrm{C}_{16: 1} \omega 7 c$ and/or iso- $\mathrm{C}_{15: 0} 2-\mathrm{OH}$; summed feature 4 comprises iso- $\mathrm{C}_{17: 1} \mathrm{I}$ and/or anteiso- $\mathrm{C}_{17: 1} \mathrm{~B}$.

MacConkey and DNA agar (Merck) and Anacker \& Ordal agar (AOA) (Anacker \& Ordal, 1955) after 5 days. Cells were tested for flexirubin pigments (Bernardet et al., 2002), Gram staining using the aminopeptidase and $\mathrm{KOH}$ reactions and for oxidase and catalase $\left(\mathrm{H}_{2} \mathrm{O}_{2}\right.$ test $)$ activities. Results are given in the species descriptions below and in Table 2. As determined by electron microscopy, cells of strains WB 1.1-56 ${ }^{\mathrm{T}}$ and $\mathrm{WB} 4.2-33^{\mathrm{T}}$ lacked flagella (not shown). Physiological properties were determined by using the commercial API ZYM and API 20NE systems (bioMérieux), as well as the GN MicroPlate system (Biolog), according to the manufacturers' instructions. API ZYM tests were read after $6 \mathrm{~h}$ incubation while API 20NE and GN MicroPlate tests were read after $48 \mathrm{~h}$. Incubation was at $25^{\circ} \mathrm{C}$. Also investigated were gliding motility (hanging drop technique; 
Table 2. Biochemical characteristics that differentiate members of the two novel genospecies, F. saccharophilum DSM $1811^{\top}$ and F. frigidimaris DSM $15937^{\top}$ as generated by the API and Biolog substrate panels

All data are from this study. The following reactions gave the same result for all strains. Positive: API ZYM - production of alkaline phosphatase, leucine arylamidase, valine arylamidase and acid phosphatase; API 20NE - production of $\beta$-galactosidase, assimilation of glucose and $\mathrm{N}$-acetylglucosamine; Biolog - utilization of dextrin, $\mathrm{N}$-acetyl-D-glucosamine, gentiobiose, $\alpha$-D-glucose, maltose, D-mannose, D-galacturonic acid, L-glutamic acid and glycyl L-glutamic acid. Positive or weakly positive: API ZYM - production of naphthol-AS-BI-phosphohydrolase and $\alpha$-glucosidase. Negative: API ZYM - production of esterase, lipase, trypsin, $\alpha$-chymotrypsin, $\alpha$-galactosidase, $\beta$-glucuronidase, $\alpha$-mannosidase and $\alpha$-fucosidase; API 20NE - production of indole and assimilation of D-glucose, L-arginine, potassium gluconate, capric acid, adipic acid, malic acid, phenylacetic acid and potassium gluconate; Biolog - utilization of adonitol, i-erythritol, myo-inositol, lactulose, D-psicose, L-rhamnose, D-sorbitol, xylitol, acetic acid, cis-aconitic acid, formic acid, L-fucose, D-galactonic acid lactone, D-gluconic acid, D-glucosaminic acid, D-glucuronic acid, $\alpha$-hydroxybutyric acid, $\beta$-hydroxybutyric acid, $\gamma$-hydroxybutyric acid, $p$-hydroxyphenylacetic acid, itaconic acid, $\alpha$-ketoglutaric acid, DL-lactic acid, malonic acid, propionic acid, quinic acid, D-saccharic acid, sebacic acid, succinic acid, bromosuccinic acid, succinamic acid, glucuronamide, D-alanine, L-histidine, hydroxy-L-proline, L-leucine, L-phenylalanine, L-proline, L-pyroglutamic acid, D-serine, L-serine, DL-carnitine, $\gamma$-aminobutyric acid, urocanic acid, inosine, uridine, thymidine, phenylethylamine, putrescine, 2-aminoethanol, 2,3-butanediol, glycerol, DL- $\alpha$-glycerol phosphate, glucose 1-phosphate and glucose 6-phosphate.

\begin{tabular}{|c|c|c|c|c|c|c|}
\hline \multirow[t]{2}{*}{ Characteristic } & \multicolumn{2}{|c|}{ F. aquidurense sp. nov. } & \multirow{2}{*}{$\begin{array}{l}\text { F. saccharophilum } \\
\text { DSM } 1811^{\mathrm{T}}\end{array}$} & \multicolumn{2}{|c|}{ F. hercynium sp. nov. } & \multirow{2}{*}{$\begin{array}{l}\text { F. frigidimaris } \\
\text { DSM } 15937^{T}\end{array}$} \\
\hline & WB $1.1-56^{T}$ & $\begin{array}{l}\text { WB 1.1-04, } \\
\text { WB 1.1-14, } \\
\text { WB 1.1-57, } \\
\text { WB 1.1-63 }\end{array}$ & & WB $4.2-33^{\mathrm{T}}$ & $\begin{array}{l}\text { WB } 4.1-86, \\
\text { WB } 4.2-32, \\
\text { WB } 4.2-34, \\
\text { WB } 4.2-78\end{array}$ & \\
\hline \multicolumn{7}{|l|}{ API ZYM } \\
\hline \multicolumn{7}{|l|}{ Production of: } \\
\hline Esterase lipase & - & $\mathrm{W}^{\star},-$ & - & $\mathrm{W}$ & $\mathrm{W},-$ & $\mathrm{W}$ \\
\hline Cystine arylamidase & w & $\mathrm{w}$ & - & - & - & - \\
\hline$\beta$-Galactosidase & w & $\mathrm{w},-$ & + & - & - & $\mathrm{W}$ \\
\hline$\beta$-Glucosidase & - & - & - & + & + & + \\
\hline$N$-Acetyl- $\beta$-glucosaminidase & + & + & + & - & - & + \\
\hline \multicolumn{7}{|l|}{ API $20 \mathrm{NE}$} \\
\hline Nitrate reduction & - &,+- & - & + & + & - \\
\hline Urease production & - & - & + & - & - & - \\
\hline Aesculin hydrolysis & + & + & - & + & + & + \\
\hline Gelatin hydrolysis & - & - & + & + &,+- & + \\
\hline \multicolumn{7}{|l|}{ Assimilation of: } \\
\hline L-Arabinose & + & + & + & - &,-+ & + \\
\hline D-Mannose & + & + & - & + & + & + \\
\hline D-Mannitol & - & - & + & + & + & + \\
\hline D-Maltose & + & + & - & + & + & + \\
\hline Trisodium citrate & - & - & - & + &,+- & - \\
\hline \multicolumn{7}{|l|}{ Biolog } \\
\hline \multicolumn{7}{|l|}{ Utilization of: } \\
\hline$\alpha$-Cyclodextrin & + &,$+ \mathrm{w}$ & - & + & + & + \\
\hline Glycogen & - & - & $\mathrm{W}$ & + & + & + \\
\hline Tween 20 & - &,-- & - & - &,$- \mathrm{w}$ & - \\
\hline Tween 80 & - & $\mathrm{w},-$ & - & - & - & - \\
\hline$N$-Acetyl-D-galactosamine & - &,-+ & - & $\mathrm{w}$ &,$- \mathrm{w}$ & $\mathrm{w}$ \\
\hline L-Arabinose & - &,-+ & + & - &,+- & - \\
\hline D-Arabitol & - & - & - & + & + & - \\
\hline D-Cellobiose & - & $\mathrm{w},+,-$ & - & + & + & $\mathrm{w}$ \\
\hline D-Fructose & + &,+- & + & + & + & + \\
\hline D-Galactose & - &,-+ & + & + & + & $\mathrm{W}$ \\
\hline$\alpha$-D-Lactose & - &,-+ & - & - & - & - \\
\hline D-Melibiose & - &,-+ & - & - & - & + \\
\hline Methyl $\beta$-D-glucoside & - &,$- \mathrm{W}$ & - & + &,$+ \mathrm{w}$ & + \\
\hline D-Raffinose & - & - & - & - & - & + \\
\hline Sucrose & - &,-+ & + & - & - & + \\
\hline
\end{tabular}


Table 2. cont.

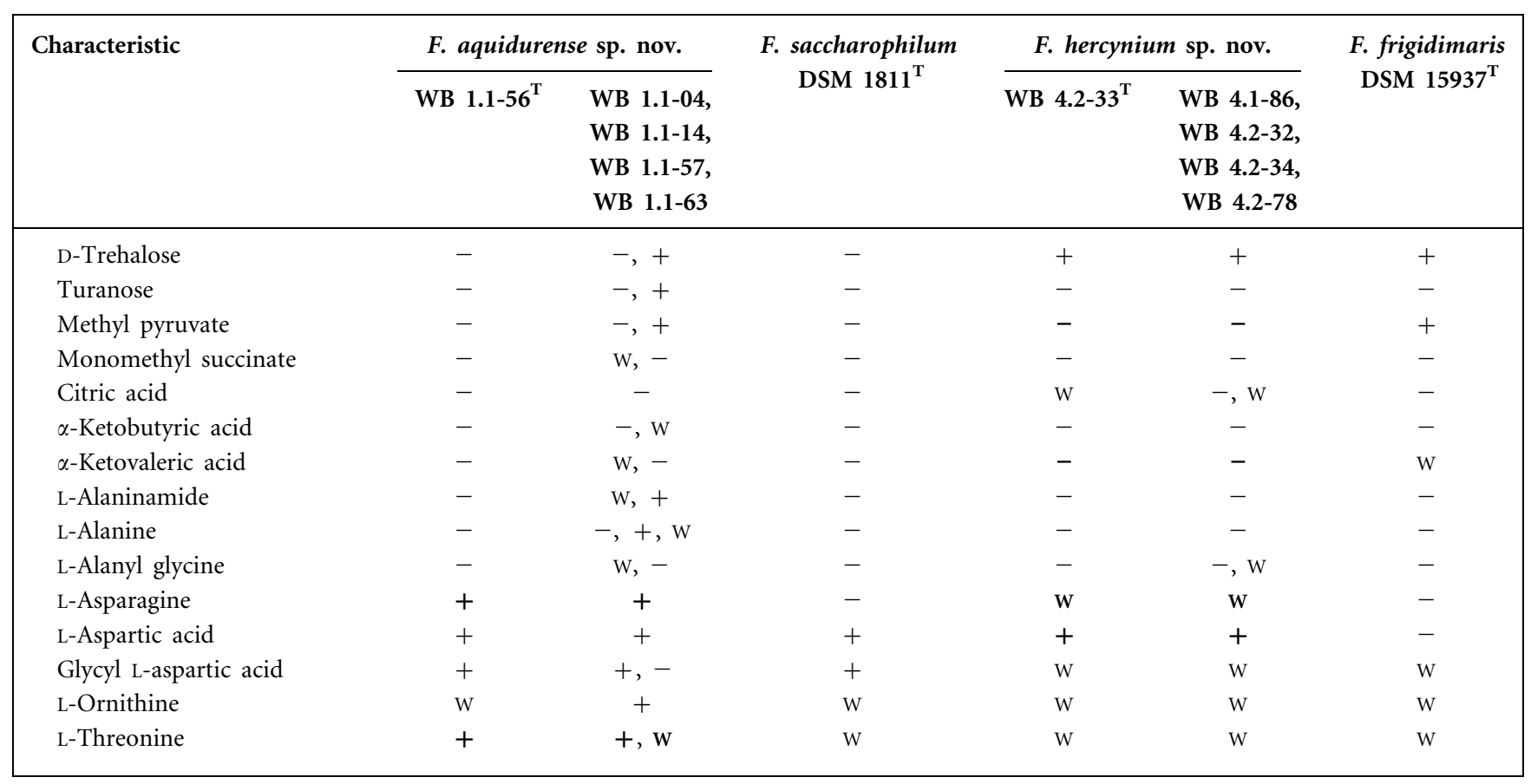

${ }^{*}$ Scoring according to API instructions was translated as follows: 5 and 4, + (positive); 3, w (weak); 2, 1 and 0 , - (negative). In those cases where strains of a given cluster differ in their reaction, the dominant reaction is listed first. Reactions in which the new strain clusters differ from the phylogenetically neighbouring species are indicated in bold.

Bernardet et al., 2002), formation of coccoid degenerative cells (spheroplasts; phase-contrast microscopy), degradation of casein (Reichenbach \& Dworkin, 1981), DNA (by using DNA agar from Difco), cellulose (strip of Whatman paper No. 1 in M67 broth), starch and L-tyrosine (Barrow \& Feltham, 1993) and production of diffusible pigments on Ltyrosine agar. Reactions were read after 3-10 days. Microaerophily was tested by the candle jar method (Gerhardt et al., 1981).

The two novel strain clusters differed from each other in several physiological reactions, and both could clearly be distinguished from the type strains of F. saccharophilum and $F$. frigidimaris (Table 2). Identical reactions for the strains investigated are listed in the legend to Table 2. For the following properties, strains related to $\mathrm{WB} 4.2-33^{\mathrm{T}}$ showed a larger number of positive reactions (at least $80 \%$ of strains) in the substrate test panel supplied than those strains related to strain $\mathrm{WB} 1.1-56^{\mathrm{T}}$ : $\beta$-glucosidase, glycogen, gelatin, trisodium citrate, D-arabitol, D-galactose, D-mannitol, methyl $\beta$-D-glycoside and $\mathrm{D}$-trehalose. Positive reactions for at least $80 \%$ of the strains related to $\mathrm{WB} 1.1-56^{\mathrm{T}}$ and negative reactions for the strains related to $\mathrm{WB} 4.2-33^{\mathrm{T}}$ were found for cystine arylamidase, $N$-acetyl- $\beta$-glucosaminidase, $\beta$-galactosidase and L-arabinose (Table 2).

In conclusion, the novel strains have been shown to be phylogenetically related to members of the genus Flavobacterium (Fig. 1; Brambilla et al., 2007) and based on similarities in Gram-negative staining behaviour, chemoheterotrophy, fatty acid profiles, the presence of flexirubin pigments and base composition of DNA. They also show the typical morphological and cultural characteristics of members of the genus Flavobacterium as given by Bernardet et al. (1996) in their emended description of the genus. Strains WB $1.1-56^{\mathrm{T}}$ are $\mathrm{WB} 4.2-33^{\mathrm{T}}$ show less than $98.0 \% 16 \mathrm{~S}$ rRNA gene sequence similarity to their closest phylogenetic neighbours and have DNA-DNA relatedness values distinctly lower than $70 \%$, the threshold value considered for species delineation (Wayne et al., 1987). As the two genospecies show sufficient intra-cluster coherence with respect to phenotype, fatty acid profiles and 16S rRNA gene sequence similarities, while showing sufficient differences among each other and their closest recognized neighbours in phenotypic properties to allow their phenotypic identification, we propose the description of two novel species, Flavobacterium aquidurense sp. nov. and Flavobacterium hercynium sp. nov.

\section{Description of Flavobacterium aquidurense sp. nov.}

Flavobacterium aquidurense (a.qui.du.ren'se. L. fem. n. aqua water; L. fem. adj. durus hard; N.L. neut. adj. aquidurense pertaining to hard water).

Gram-negative, aerobic and microaerobic rods $(0.9 \times 2.8 \mu \mathrm{m})$. Growth occurs between 13 and $30^{\circ} \mathrm{C}$ with 
an optimal temperature between 19 and $28^{\circ} \mathrm{C}$; no growth occurs below $8{ }^{\circ} \mathrm{C}$ or above $31.5^{\circ} \mathrm{C}$. Growth occurs between pH 6.0 and 6.6 with an optimal pH of 6.4. Growth occurs at $\mathrm{NaCl}$ concentrations between 0 and $1 \%$. No gliding motility; no flagella. Non-swarming; local spreading around colonies (maximum $6 \mathrm{~mm}$ ) is observed on some growth media. Spheroplasts form after 3-4 days in R2A broth. Colonies formed on M67 agar after 5 days incubation are 3-8 $\mathrm{mm}$ in diameter, yellowish, spreading, irregular, flat with a slight rise at the centre but not umbonate, smooth, shiny, glistening, transparent and butyrous with filamentous margins. Colonies on AOA are zinc yellow, spreading, punctiform, flat with a central rise and with undulated margins fading to transparent. Colonies on R2A are 1-2 $\mathrm{mm}$ in diameter (mean $1.8 \mathrm{~mm}$ ), zinc yellow, spreading, circular, convex, entire, smooth, translucent and butyrous with filamentous margins. Colonies on DNA agar are $0.9-1.5 \mathrm{~mm}$ in diameter (mean $1 \mathrm{~mm}$ ), maize yellow, circular, non-spreading, convex-pyramidal, smooth and translucent to slightly opaque in the centre with undulated margins. Colonies on TSA are $0.7-1 \mathrm{~mm}$ in diameter, honey yellow, non-spreading, circular, convex, smooth, translucent and butyrous with undulate margins. Colonies on NA are $2.2 \mathrm{~mm}$ in diameter, maize yellow, have a central bump, are umbonate, smooth and translucent with undulate margins; irregular swarming is observed. No growth on MacConkey agar. Colonies do not adhere to the agar. Non-diffusible flexirubin pigments are present. Catalase- and oxidase-positive. Starch, L-tyrosine and casein are degraded. A brown pigment is produced on Ltyrosine agar. Cellulose, DNA and agar are not hydrolysed. Other physiological reactions are given in Table 1. Cells contain iso- $\mathrm{C}_{15: 0}$, iso- $\mathrm{C}_{17: 0} 3-\mathrm{OH}$, iso- $\mathrm{C}_{15: 0} 3-\mathrm{OH}$, iso$\mathrm{C}_{17: 1} \omega 9 c, \mathrm{C}_{15: 0}$ and summed feature $3\left(\mathrm{C}_{16: 1} \omega 7 c\right.$ and/or iso- $\mathrm{C}_{15: 0}$ 2-OH) as main fatty acids. The DNA G+C content of the type strain is $33.5 \mathrm{~mol} \%$.

The type strain, WB $1.1-56^{\mathrm{T}} \quad\left(=\mathrm{DSM} \quad 18293^{\mathrm{T}}=\mathrm{CIP}\right.$ $\left.109242^{\mathrm{T}}\right)$, was isolated from the spring of the Westerhöfer Bach, Westerhof, $40 \mathrm{~km}$ north of Göttingen, Germany.

\section{Description of Flavobacterium hercynium sp. nov.}

Flavobacterium hercynium (her.cy'ni.um. L. neut. adj. hercynium pertaining to Hercynia, the Roman name for a mountain range, including the Harz Mountains, that forms the southern border of the North German plain).

Gram-negative, aerobic and microaerobic rods $(0.7-0.8 \times$ 5.8-6.3 $\mu \mathrm{m}$ ). Growth occurs between 12 and $29^{\circ} \mathrm{C}$ with an optimal growth temperature of $20-27^{\circ} \mathrm{C}$; no growth occurs below $7{ }^{\circ} \mathrm{C}$ or above $30.5^{\circ} \mathrm{C}$. Growth occurs between $\mathrm{pH} 6.4$ and 8.0 with an optimum of $\mathrm{pH}$ 6.4-7.8. Growth occurs at $\mathrm{NaCl}$ concentrations between 0 and $1 \%$. Motile by gliding; no flagella are observed. Cells glide on M67, AOA, NA and R2A media but not on DNA agar or TSA. Spheroplasts form after 3-4 days in R2A broth. On M67 agar growth is brown beige on plates and orange-yellow on loops; colony surface is effuse, irregular, glistening, spreading and with irregular lobate margins. Growth on AOA is brown beige; the surface is smooth, flat, translucent to transparent, and no margin is observed. Growth on R2A is dark orange to yellow; the surface is flat, glistening, translucent to transparent, with thinly lobate margins. Colonies on DNA agar are $4-8 \mathrm{~mm}$ in diameter, maize yellow, circular, non-spreading, umbonate, glistening, slightly irregular and translucent with undulate margins. Colonies on TSA are $4-7 \mathrm{~mm}$ in diameter, maizeyellow, non-spreading, circular, slightly umbonate, smooth, glistening and slightly irregular with undulate margins. Growth on NA is maize-yellow, glistening, irregular, flat and translucent. No growth is observed on MacConkey agar. Colonies do not adhere to the agar. Non-diffusible flexirubin pigments are present. Catalase- and oxidase-positive. Starch, L-tyrosine and casein are degraded. A brown pigment is produced on L-tyrosine agar. Cellulose, DNA and agar are not hydrolysed. Cells contain iso- $\mathrm{C}_{15: 0}$, iso$\mathrm{C}_{17: 0} 3-\mathrm{OH}$, iso- $\mathrm{C}_{15: 0} 3-\mathrm{OH}$ and summed feature 3 $\left(\mathrm{C}_{16: 1} \omega 7 \mathrm{c}\right.$ and/or iso- $\left.\mathrm{C}_{15: 0} 2-\mathrm{OH}\right)$ as main fatty acids. The DNA G $+\mathrm{C}$ content of the type strain is $37.5 \mathrm{~mol} \%$.

The type strain, WB $4.2-33^{\mathrm{T}}\left(=\mathrm{DSM} \quad 18292^{\mathrm{T}}=\mathrm{CIP}\right.$ $109241^{\mathrm{T}}$ ), was isolated from a site about $320 \mathrm{~m}$ downstream of the spring of the Westerhöfer Bach, Westerhof, $40 \mathrm{~km}$ north of Göttingen, Germany.

\section{Acknowledgements}

This project forms part of the Research Unit 571 'Geobiology of Organo- and Biofilms', funded by the German Research Foundation (Sta 184/19-2; DFG-FOR 571; publication no. 6). We thank Hans Trüper for his advice with etymology. We thank Bettina Sträubler and Peter Schumann (DNA-DNA reassociation), Anja Frühling (phenotypic tests), Gabriele Pötter (fatty acid analysis) for technical advice and Manfred Rohde for help with electron microscopy.

\section{References}

Anacker, R. L. \& Ordal, E. J. (1955). Study of a bacteriophage infecting the myxobacterium Chondrococcus columnaris. J Bacteriol 70, 738-741.

Aslam, Z., Im, W.-T., Kim, M. K. \& Lee, S.-T. (2005). Flavobacterium granuli sp. nov., isolated from granules used in a wastewater treatment plant. Int J Syst Evol Microbiol 55, 747-751.

Barrow, G. I. \& Feltham, R. K. A. (1993). Cowan and Steel's Manual for the Identification of Medical Bacteria, 3rd edn. Cambridge: Cambridge University Press.

Bergey, D. H., Harrison, F. C., Breed, R. S., Hammer, B. W. \& Huntoon, F. M. (editors) (1923). Bergey's Manual of Determinative Bacteriology. Baltimore: Williams \& Wilkins.

Bernardet, J.-F. \& Bowman, J. P. (2005). The genus Flavobacterium. In The Prokaryotes: an Evolving Electronic Resource for the Microbiological Community, release 3.20. Edited by M. Dworkin, S. Falkow, E. Rosenberg, K. H. Schleifer \& E. Stackebrandt. New York: Springer. http://141.150.157.117:8080/prokPUB/index.htm

Bernardet, J.-F., Nakagawa, Y. \& Holmes, B. (2002). Proposed minimal standards for describing new taxa of the family Flavobacteriaceae and emended description of the family. Int J Syst Evol Microbiol 52, 1049-1070. 
Bernardet, J.-F., Segers, P., Vancanneyt, M., Berthe, F., Kersters, K. \& Vandamme, P. (1996). Cutting a Gordian knot: emended classification and description of the genus Flavobacterium, emended description of the family Flavobacteriaceae, and proposal of Flavobacterium hydatis nom. nov. (basonym, Cytophaga aquatilis Strohl and Tait 1978). Int J Syst Bacteriol 46, 128-148.

Brambilla, E., Päuker, O., Cousin, S., Steiner, U., Reimer, A. \& Stackebrandt, E. (2007). High phylogenetic diversity of Flavobacterium spp. in a hardwater creek, Harz Mountain, Germany. Org Divers Evol (in press).

Cashion, P., Holder-Franklin, M. A., McCully, J. \& Franklin, M. (1977). A rapid method for the base ratio determination of bacterial DNA. Anal Biochem 81, 461-466.

De Ley, J., Cattoir, H. \& Reynaerts, A. (1970). The quantitative measurement of DNA hybridization from renaturation rates. Eur J Biochem 12, 133-142.

De Soete, G. (1983). A least squares algorithm for fitting additive trees to proximity data. Psychometrika 48, 621-626.

DSMZ (2001). Catalogue of Strains, 7th edn. Braunschweig, Germany: DSMZ. http://www.dsmz.de

Escara, J. F. \& Hutton, J. R. (1980). Thermal stability and renaturation of DNA in dimethyl sulfoxide solutions: acceleration of the renaturation rate. Biopolymers 19, 1315-1327.

Felsenstein, J. (1985). Confidence limits on phylogenies: an approach using the bootstrap. Evolution 39, 783-791.

Felsenstein, J. (1993). PHYLIP (phylogeny inference package), version 3.5.1. Distributed by the author. Department of Genome Sciences, University of Washington. Seattle, USA.

Frank-Kamenetskii, F. (1971). Simplification of the empirical relationship between melting temperature of DNA, its GC content and concentration of sodium ions in solution. Biopolymers 10, 2623-2624.

Gerhardt, P., Murray, R. G. E., Costilow, R. N., Nester, E. W., Wood, W. A., Krieg, N. R. \& Phillips, G. R. (1981). Manual of Methods for General Bacteriology. Washington, DC: American Society for Microbiology.

Horn, M. A., Ihssen, J., Matthies, C., Schramm, A., Acker, G. \& Drake, H. L. (2005). Dechloromonas denitrificans sp. nov., Flavobacterium denitrificans sp. nov., Paenibacillus anaericanus sp. nov. and Paenibacillus terrae strain $\mathrm{MH} 72, \mathrm{~N}_{2} \mathrm{O}$-producing bacteria isolated from the gut of the earthworm Aporrectodea caliginosa. Int J Syst Evol Microbiol 55, 1255-1265.

Humphry, D. R., George, A., Black, G. W. \& Cummings, S. P. (2001). Flavobacterium frigidarium sp. nov., an aerobic, psychrophilic, xylanolytic and laminarinolytic bacterium from Antarctica. Int J Syst Evol Microbiol 51, 1235-1243.

Huß, V. A. R., Festl, H. \& Schleifer, K. H. (1983). Studies on the spectrophotometric determination of DNA hybridization from renaturation rates. Syst Appl Microbiol 4, 184-192.

Kämpfer, P. \& Kroppenstedt, R. M. (1996). Numerical analysis of fatty acid patterns of coryneform bacteria and related taxa. Can J Microbiol 42, 989-1005.

Kim, B.-Y., Weon, H. Y., Cousin, S., Yoo, S.-H., Kwon, S.-W., Go, S. J. \& Stackebrandt, E. (2006). Flavobacterium daejeonense sp. nov. and Flavobacterium suncheonense sp. nov., isolated from greenhouse soil in Korea. Int J Syst Evol Microbiol 56, 1635-1638.

McCammon, S. A. \& Bowman, J. P. (2000). Taxonomy of Antarctic Flavobacterium species: description of Flavobacterium gillisiae sp. nov., Flavobacterium tegetincola sp. nov. and Flavobacterium xanthum sp. nov., nom. rev. and reclassification of [Flavobacterium] salegens as Salegentibacter salegens gen. nov., comb. nov. Int J Syst Evol Microbiol 50, 1055-1063.

Miller, L. T. (1982). A single derivatization method for bacterial fatty acid methyl esters including hydroxy acids. J Clin Microbiol 16, 584-586.

Nogi, Y., Soda, K. \& Oikawa, T. (2005). Flavobacterium frigidimaris sp. nov., isolated from Antarctic seawater. Syst Appl Microbiol 28, 310-315.

O’Sullivan, L. A., Rinna, J., Humphreys, G., Weightman, A. J. \& Fry, J. C. (2006). Culturable phylogenetic diversity of the phylum 'Bacteroidetes' from river epilithon and coastal water and description of novel members of the family Flavobacteriaceae: Epilithonimonas tenax gen. nov., sp. nov. and Persicivirga xylanidelens gen. nov., sp. nov. Int J Syst Evol Microbiol 56, 169-180.

Rainey, F. A., Ward-Rainey, N., Kroppenstedt, R. M. \& Stackebrandt, E. (1996). The genus Nocardiopsis represents a phylogenetically coherent taxon and a distinct actinomycete lineage: proposal of Nocardiopsaceae fam. nov. Int J Syst Bacteriol 46, 1088-1092.

Reichenbach, H. \& Dworkin, M. (1981). Introduction to the gliding bacteria. In The Prokaryotes, vol. 1, pp. 315-327. Edited by M. P. Starr, H. Stolp, H. G. Trüper, A. Balows \& H. G. Schlegel. Berlin: Springer.

Tamaki, H., Hanada, S., Kamagata, Y., Nakamura, K., Nomura, N., Nakano, K. \& Matsumura, M. (2003). Flavobacterium limicola sp. nov., a psychrophilic, organic-polymer-degrading bacterium isolated from freshwater sediments. Int J Syst Evol Microbiol 53, 519-526.

Van Trappen, S., Mergaert, J. \& Swings, J. (2003). Flavobacterium gelidilacus sp. nov., isolated from microbial mats in Antarctic lakes. Int J Syst Evol Microbiol 53, 1241-1245.

Van Trappen, S., Vandecandelaere, I., Mergaert, J. \& Swings, J. (2004). Flavobacterium degerlachei sp. nov., Flavobacterium frigoris sp. nov., and Flavobacterium micromati sp. nov., novel psychrophilic bacteria isolated from microbial mats in Antarctic lakes. Int J Syst Evol Microbiol 54, 85-92.

Van Trappen, S., Vandecandelaere, I., Mergaert, J. \& Swings, J. (2005). Flavobacterium fryxellicola sp. nov. and Flavobacterium psychrolimnae sp. nov., novel psychrophilic bacteria isolated from microbial mats in Antarctic lakes. Int J Syst Evol Microbiol 55, 769-772.

Wang, Z.-W., Liu, Y.-H., Dai, X., Wang, B.-J., Jiang, C.-Y. \& Liu, S.-J. (2006). Flavobacterium saliperosum sp. nov., isolated from freshwater lake sediment. Int J Syst Evol Microbiol 56, 439-442.

Wayne, L. G., Brenner, D. J., Colwell, R. R., Grimont, P. A. D., Kandler, O., Krichevsky, M. I., Moore, L. H., Moore, W. E. C., Murray, R. G. E. \& other authors (1987). International Committee on Systematic Bacteriology. Report of the ad hoc committee on reconciliation of approaches to bacterial systematics. Int $J$ Syst Bacteriol 37, 463-464.

Yi, H. \& Chun, J. (2006). Flavobacterium weaverense sp. nov. and Flavobacterium segetis sp. nov., novel psychrophiles isolated from the Antarctic. Int J Syst Evol Microbiol 56, 1239-1244.

Yi, H., Oh, H.-M., Lee, J.-H., Kim, S.-J. \& Chun, J. (2005). Flavobacterium antarcticum sp. nov., a novel psychrotolerant bacterium isolated from the Antarctic. Int J Syst Evol Microbiol 55, 637-641.

Yoon, J.-H., Kang, S.-J. \& Oh, T.-K. (2006). Flavobacterium soli sp. nov., isolated from soil. Int J Syst Evol Microbiol 56, 997-1000.

Zhu, F., Wang, S. \& Zhou, P. (2003). Flavobacterium xinjiangense sp. nov. and Flavobacterium omnivorum sp. nov., novel psychrophiles from the China No. 1 glacier. Int J Syst Evol Microbiol 53, 853-857. 